\title{
Hospitality Management Specialization Practical Courses Evaluation and Development
}

\author{
By Masooma Al-Balushi ${ }^{*}$ \& Tamer Mohamed Atef ${ }^{ \pm}$
}

\begin{abstract}
Students registered in the Tourism Department undergraduate program at the College of Arts and Social Sciences (CASS) of Sultan Qaboos University (SQU) study 12 specialization requirements courses (36 credit hours) in one of the department specializations (Tourism Management - Hospitality Management) for 4 semesters. The Hospitality Management specialization study plan comprises two practical courses "Food Production" and "Service in Hospitality". Both courses have a weekly 50-minute theoretical (In-class) foundation part complemented by a weekly 4-hour practical application part. Over the years, the location for the two courses practical application part has been a major concern, commercial properties as a training location or catering facilities on SQU premises? many questions were posed seeking to determine which location better enhances students learning experience and helps the accomplishment of courses objectives and learning outcomes. The current study aims to evaluate the teaching and learning experience of the two practical Hospitality Management Specialization courses: "Food Production" and "Service in Hospitality". End of practical application reports of students enrolled in the "Food Production" course in Fall 2018 and Fall 2019 were analyzed. A survey was distributed to Spring 2020 "Service in Hospitality" course students. Then finally, interviews with the two courses instructors were conducted in Spring 2020. Students' evaluations and responses were straight forward while instructors' comments were thorough, correlating the investigated courses to the other study plan courses showing their wholistic effect on the program sustainability. The study outcomes are important in evaluating the practical courses status leading to an enhanced teaching and learning experience and is a step towards the undergraduate program study plan reformulation and update.
\end{abstract}

Keywords: tourism, hospitality, practical courses, study plan, education, training, Oman

\section{Introduction}

All students registering in the Tourism Department at the College of Arts and Social Sciences (CASS) of Sultan Qaboos University (SQU) study the major requirements courses, which include 12 courses (34 credit hours). Students usually receive these courses during their first four semesters in the department. Students will then proceed towards the specialization requirements courses, which includes

\footnotetext{
*Assistant Professor, Tourism Department, College of Arts and Social Sciences, Sultan Qaboos University, Oman.

${ }^{ \pm}$Associate Professor, Hotel Studies Department, Faculty of Tourism and Hotels, University of Sadat City, Egypt.
} 
12 courses (36 credit hours) in one of the department specializations (Tourism Management - Hospitality Management) for 4 semesters.

The current study aims to evaluate the teaching and learning experience of the two practical Hospitality Management Specialization courses:

- Food Production Course.

- Service in Hospitality Course.

Both courses have a weekly 50-minute theoretical foundation part complemented by a weekly 4 -hour practical application ${ }^{1}$ part. Currently, the theoretical foundation takes place in a classroom setting and the practical application takes place at the SQU students" services center kitchen for the "Food Production" course and at the SQU faculty club restaurant for the "Service in Hospitality" course. It is worth noting that the maximum enrollment number for each of these two courses is set at 15 students (Please check the following link as an example of the Tourism Department enrollment figures: https://portal.squ.edu. om/sectioncounts).

\section{Arrangements for the Practical Application Part of the Courses}

- Course file is given to the field trainer, followed by an explanation of the course objectives, learning outcomes, and course topics that are going to be covered during the practical application sessions.

- The course instructor is usually present at the beginning of each training session to assure discipline and punctuality.

\section{Course Evaluation Methods}

- Classroom Questions and Answers allowed to gain continuous feedback on students learning progress and the achievement of the course objectives and learning outcomes.

- End of practical application period report is required from students to assure achievement of course objectives and learning outcomes, in addition to assessing the practical application experience status.

- A standard end of semester courses evaluation survey is sent to all students by SQU administration.

\section{Course Practical Application Location}

Based on students' feedback, the courses practical application location was changed from commercial properties to SQU onsite catering facilities (Academic

\footnotetext{
${ }^{1}$ The word "Training" is used to indicate the practical application part of the courses as well.
} 
Year: 2012-2013). The following were concerns and issues raised by students about commercial properties experience that directed the change:

- Students were trained in commercial properties which required the services of SQU transportation department to move students from SQU to the training location and vice-versa.

- Field trainers were not free to train students due to work pressure and demands.

- Students were given minimal/hard labor tasks.

The SQU onsite catering facilities usage allowed students to experience institutional operations environment while commercial operations environment is to be experienced during internship $1 \& 2$ courses.

\section{Literature Review}

Although the tourism and hospitality industry is a gold mine of employment opportunities, the industry faces challenges due to skills shortages, high turnover rates, business fluctuations, and of course costs of training (Ryan et al. 2016). Therefore, the industry seeks the help of academic institutions to provide a workready graduate with the skills and capabilities to deal with real-world challenges (Balula et al. 2019, Patiar et al. 2019).

Students themselves also expect that their tertiary education will provide them with industry-oriented curricula with real-world focused courses that include hands-on learning opportunities and thus, increase their employability chances (Schoffstall et al. 2017).

Equipping students with industry needed competences is the role of tourism and hospitality educational institutions. In the context of tourism and hospitality education, students' competencies can be understood as a collection of cognitive, functional, social, and emotional skills required for success. The tourism and hospitality curricula and competencies development and success are dependent on the efficiency of the interaction between academics, students, and industry affiliates (Dawson 2014, Mahmoud 2018).

Enrolment rates for an academic program is greatly affected by employability. Higher education institutions are under pressure to prepare students to be employable (Harvey 2010, Jauhari and Manaktola 2006). The tourism and hospitality academic programs are preoccupied by balancing theory with practical application in response to the industry ever-changing manpower skillsets (Ruhanen 2005).

While recognizing that the employability of students should be a primary goal of tourism and hospitality academic programs, curricula should be well structured and balanced including philosophical, sociological, managerial, and entrepreneurial courses to enhance students decision-making capabilities, as well as their professional work ethics (Inui et al. 2006, Atef and Al-Balushi 2015). 
Academics and instructors develop and deliver curricula, manage the educational teaching and learning experience, they play an important role in engaging students throughout courses (Nguyen and LeBlanc 2021, Odio et al. 2014, Tucker and Clarke 2014). But this is only one side of the coin, the students' own motivation and enthusiasm makes the difference (Wang 2013, Chen et al. 2018).

Growth in numbers of tourism and hospitality academic programs has increased the demand for faculty positions. Colleges and universities look for distinctive faculty members. The lack of practical industry work experience among academics is a pressing issue. This would negatively affect students learning experience, and of course, would not guarantee them a smooth transition to the industry workforce (Nguyen and LeBlanc 2021, Tepeci et al. 2001, Wu et al. 2014).

Ongoing efforts have been made to address the needs of stakeholders in terms of learning outcomes, curricula, educational conceptual models, and teaching methods. Traditionally, hotels, restaurants, and resorts were dominant study areas within tourism and hospitality education. New study areas have been introduced to cope with the ever-changing industry demands such as convention and exhibition management, events, cruises, theme parks, and clubs, widening the spectrum of hospitality and tourism curricula (Cho et al. 2006, Lee et al. 2010).

The following are suggested perspectives to be considered for tourism and hospitality curricula development (Ring et al. 2009, Atef and Al-Balushi 2017):

1. Global tourism and hospitality trends.

2. Critical and flexible thinking.

3. Professionalism and Business ethics.

4. Management and entrepreneurial orientation.

5. Information Technology.

Education and Training do not refer to the same activity. Education is the acquisition of knowledge, skills, and moral values on a broad level, whereas Training is directed towards development of specific skills and applied knowledge leading to change in behaviour and attitude. The hospitality industry uses training to improve current job skills, prepare for career advancement, teach new or changing occupational requirements (Tannenbaum et al. 1991, Peterson and Hicks 1996, Statt 2000). Evaluation is a must in training as it is in education. Training evaluation is the attempt to obtain feedback on the training program conducted and to assess its efficiency (Go et al. 1996, Sommerville 2007).

Tourism and hospitality academic institutions place great importance on practical applications and forms of training programs. A well-educated, well trained, and skilled graduate is the demand of today's tourism and hospitality job market (Canny 2002, Ng and Burke 2006, Koc et al. 2014).

Generally, training methods could be gathered under the following categories (Forrest 1996, Go et al. 1996, Statt 2000, Boella and Goss-Turner 2005, Sommerville 2007): 
- On the job training: Training is delivered directly to employees while on the job.

- Job rotation or cross-training: Train employees in other areas out of their direct jobs.

- Off the job training: Usually training is provided in a traditional classroom setting.

- Other training methods: Which include internships, role playing, case studies, etc.

One of the most effective progressive on the job training techniques is "Job Shadowing" defined as the practice of accompanying a designated employee to see and learn from this employee's on-the-job skills demonstration. In job shadowing for education, a student would accompany an experienced employee during performing his job duties and responsibilities. Shadowing is an important practice for college students to experience a particular position to ascertain its suitability for them and is one of the more holistic ways to ensure readiness for practice (Shardlow and Doel 1996, Gould 2000, Rony 2019).

Shadowing is a superior educational activity. Its benefits exceed those of speeches, speakers, cases, and educational videos (McCarthy and McCarthy 2006). It can be a great tool for college students to explore potential careers prior to committing to a specific one by finding out what happens in a particular job on daily basis (Mader et al. 2017, Heathfield 2020).

\section{Methodology}

End of practical application reports of students enrolled in the "Food Production" course in Fall 2018 (8 reports) and Fall 2019 (9 reports) were analyzed. A survey was distributed to Spring 2020 "Service in Hospitality" course students (10 students). Then finally interviews with the two courses instructors (2 instructors - 2 interviews) were conducted in Spring 2020. The application of different research tools on the two courses allowed the evaluation of several aspects through different perspectives:

- Course practical application location.

- Course practical application learning experience.

- In class teaching and learning experience.

- Overall students' perceptions.

- Overall instructors' perceptions.

- Pros and cons of the current practical courses model.

- Overall study plan amendment and development.

\section{Food Production Course}

This course is offered as part of the Fall courses. Upon the end of the practical application sessions, students are required to prepare and submit a report that 
entails various aspect of the training experience and their overall perceptions. For the course instructors those reports are a means to assure the achievement of course objectives and learning outcomes and to assess the practical training experience status. Reports of students enrolled in the course in Fall 2018 and Fall 2019 were analyzed; see Table 1 . A six-stage content analysis process suggested by Finn et al. (2000) was applied on students' reports which includes: aim and object identification, sample selection, recording scheme development, data reduction, analysis, and findings reporting. Furthermore, students' reflections were grouped and analyzed following SWOT analysis approach, to assess training experience strengths, weaknesses, opportunities, and threats.

Table 1. Respondents Status (Food Production Course)

\begin{tabular}{|l|c|c|}
\hline Semester & Fall 2018 & Fall 2019 \\
\hline Enrolled Students & 8 & 9 \\
\hline Number of Papers Analyzed & 8 & 9 \\
\hline
\end{tabular}

Service in Hospitality course

This course is offered as part of the Spring courses. A survey was distributed to Spring 2020 "Service in Hospitality" course students on week 6 of study to evaluate the ongoing course status allowing for any necessary corrective actions and amendments to be taken when required; see Table 2 .

Table 2. Respondents Status (Service in Hospitality Course)

\begin{tabular}{|l|c|}
\hline Semester & Spring 2020 \\
\hline Enrolled Students & 11 \\
\hline Number of Surveys Returned and Analyzed & 10 \\
\hline
\end{tabular}

\section{Instructors Interviews}

For nearly 10 years (Fall 2009 till Spring 2020) two instructors were responsible for teaching those two courses. Semi structured interviews were conducted with the two instructors in Spring 2020, their comments were quoted and analyzed.

\section{Discussion}

At the beginning of each semester the students are given a course file for each course they are registered in. The course file contains the course description, objectives, and learning outcomes.

\section{Part A: Food Production Course}

This course covers management considerations on quantity food production for schools, health care, hotels and other large volume institutions. 


\section{The Course Objectives}

The course intends to:

- Demonstrate principles of sanitation and food safety.

- Explain the types of food production operations.

- Demonstrate the use of quantity food production equipment.

- Explain principles of menu planning.

- Explain the basic cooking principles and techniques of quantity food production.

- Discuss methods and procedures for purchasing, receiving, storage and issuing.

\section{The Course Learning Outcomes}

Upon completion of this course the student will be able to:

- Apply principles of sanitation and food safety.

- Demonstrate an understanding of quantity and quality food planning and production.

- Analyze menus for types, content, costs and profitability.

- Demonstrate an understanding of quantity food production equipment.

- Identify and solve food management issues.

The following section conveys the points raised by students and their perception of the educational experience (ST=Student, FL=Fall Semester):

\section{Course and Practical Training Aim and Objectives}

Based on the students statements it was clear that course objectives and learning outcomes were adhered to and collectively achieved which poses no problem when it comes to teaching and learning practices.

“...see and apply what we got in the lecture..." (St1-FL18) (St4-FL19)

“...I learned about machines and equipment...” (St3-FL18) (St5-FL19)

“...I learned about personal hygiene and HACCP ..." (St3-FL18) (St2-FL19)

"...I know what types of tools they use like knives, peelers, drainers, and blenders..." (St5-FL18)

“...I became more familiar with the kitchen sections..." (St6-FL18)

"...I learned how to organize the work..." (St1-FL18) (St5-FL19)

"...I learned how to respect the staff and being polite and smiley with them..." (St5FL18)

“...we learned how the kitchen staff are divided...." (St2-FL18) (St7-FL19)

“...I have learned how to work in groups..." (St3-FL18) (St7-FL19)

"...they showed us what we studied in real life..." (St1-FL18) (St4-FL19) 


\section{Pretraining/Personal Hygiene and Safety}

As arranged with the trainers, the executive chef (field trainer) explained to the students the basic essential kitchen rules, started with some sanitation, safety, and hygiene rules, then talked about the handling of food items:

- Safe lifting.

- Hands washing and no smoking policy.

- Handling kitchen tools and equipment.

- Safe food handling.

- Food contamination.

"...there was an orientation around the kitchen, but first they gave us some safety tips..." (St2-FL18) (St6-FL19)

"...everyone should wear the appropriate uniform, and this includes coats, aprons, and hair covers..." (St2-FL18) (St9-FL19)

"...first, we met the supervisor, we discussed the training method, we were briefed about the dress code...we had to wear the right outfit...non-slip shoes..." (St7-FL18) (St1-FL19)

"...the chef took us on a tour around the kitchen sections, and they are: hot kitchen, cold kitchen, butcher, bakery, dry store, chiller store..." (St4-FL18) (St7-FL18)

"...the chef told us about personal hygiene, we already studied in class..." (St7FL18)

"...we tried to use some equipment in the right way..." (St2-FL18) (St8-FL19)

\section{Practical Work and Learning Experience}

Students were distributed over the various kitchen sections each with his own training schedule. This rotation scheme allowed the students the benefits of one on one training experience, giving a chance for students to pose questions and get answers without crowding the area or the trainer feeling under the stress of supervising many trainees at the same time.

“...we were distributed, each student in a different section..." (St1-FL19)

"...I have rotated the different areas and learned about them...when I gained an acceptable amount of knowledge, I move to another section..." (St8-FL18)

"...in the kitchen the chef was giving all the information that we need beside answering every question and inquiry we have..." (St3-FL18) (St8-FL19)

"...at the end of every training day we had a meeting with the chef to see if we had any questions or comments..." (St7-FL18)

\section{Cooking}

Cooking itself is not a course objective nor an outcome but quantity and quality food planning and production is the target. Students' statements show that to a great extent these aspects were covered through the specific kitchen activities they had. Appreciating the staff efforts done to feed a large number of patrons at 
the same time and the control done by supervisors and managers was a major goal that was also achieved.

"...I have assisted the chefs in cooking several dishes such as rice, roast chicken, fried chicken, grilled fish, and some pasta dishes..." (St5-FL18)

"...I have learned that size of the vegetable cut matters and has to be precise and consistent..."(St1-FL19)

“...it is not like cooking at home...chefs follow standardized recipes..." (St8-FL18)

“...cooking for thousands every day...." (St6-FL18)

“... it is not only daily meals; they are cooking also for events..." (St6-FL18)

\section{Receiving and Storing}

Students were able to see in practice how the procurement cycle takes place. This allowed them to understand the food cycle and how each cycle phase affects the whole food production and service operations.

"...I was helping in the receiving area where all deliveries are checked before storage..." (St7-FL18)

“...they also told me about food storage..." (St1-FL18) (St3-FL19)

"...there are five food stores or freezers in the student services center at Sultan Qaboos University...” (St2-FL18) (St4-FL19)

\section{Overall Experience Evaluation}

The overall students' feedback was positive indicating that the practical application complemented the theoretical part harmoniously.

“...training in the student services kitchen at Sultan Qaboos University was a useful one..." (St7-FL18)

"...I have learned from this experience that planning and organizing are the key to success..." (St8-FL18)

"...working in such place gives you the power and the knowledge..." (St3-FL18) (St2-FL19)

\section{SWOT Analysis}

Based on the analysis of students feedback the following SWOT analysis was formulated to help identify strengths, weaknesses, opportunities, and threats related to the practical training course (See Table 3): 
Table 3. SWOT Analysis

\begin{tabular}{|c|c|}
\hline Strengths & Weaknesses \\
\hline $\begin{array}{l}\text { - Orientation and induction of students is } \\
\text { well executed before training startup. } \\
\text { - It is on campus requires no transportation } \\
\text { services. } \\
\text { - It familiarizes the students with institutional } \\
\text { food service operations. } \\
\text { - Training supervision is easy being on } \\
\text { campus. } \\
\text { - Expands students' awareness of areas other } \\
\text { than food production to areas like receiving } \\
\text { and storage. }\end{array}$ & $\begin{array}{l}\text { - Only } 4 \text { hours per week. } \\
\text { - The shift work system is not applied. }\end{array}$ \\
\hline Opportunities & Threats \\
\hline $\begin{array}{l}\text { - Can make use of other SQU facilities such } \\
\text { as, the faculty club and staff club kitchens } \\
\text { to train larger numbers of students. } \\
\text { - To build an educational kitchen specially } \\
\text { designed for students training. }\end{array}$ & $\begin{array}{l}\text { - Interaction with trainers might be } \\
\text { uncomfortable to trainees. } \\
\text { - Absence and not following practical } \\
\text { training scheduled phases. }\end{array}$ \\
\hline
\end{tabular}

\section{Part B: Service in Hospitality Course}

This course will enable students to concentrate on a comprehensive study of dining service operations within the food and beverage industry that will include American, English, French and Russian service. The student will be able to plan service, write standards, schedule labor, and execute service for groups of customers.

\section{The Course Objectives}

The course intends to provide students with the ability to:

- Recognize various types of restaurants.

- Describe common and unique tableware used in dining room service.

- Recognize the different types of service.

- Identify customer service requirements in a dining room setting.

- Develop a labor schedule for operations.

\section{The Course Learning Outcomes}

Upon completion of this course the student will be able to:

- Identify the various types of restaurants.

- Explain the differences between types of service.

- Demonstrate knowledge and understanding of food and beverage operations management.

- Apply human relations and technical skills required in the service of food and beverage. 


\section{Questionnaire Evaluation}

\section{The Teaching Approach Used for the Course}

The second practical course for Hospitality Management Specialization is Service in Hospitality, respondents were asked to indicate their perception of the teaching approach used by the course instructor in class, a concise description of three teaching approaches was provided to overcome any ambiguities as follows:

- Student-centered (Students interact with instructor and one another).

- Teacher-centered (Instructor talks, and students listen).

- Mixed method (Student-centered with Teacher-centered).

Eighty percent of the respondents declared that the approach used was "Mixed Methods"; see Table 4 for course teaching approach. This approach allows students to take role in the teaching and learning experience after the instructor has given some ground information to enhance students' knowledge of the topic discussed.

Table 4. Course Teaching Approach

\begin{tabular}{|l|c|c|}
\hline Approach & Frequency & Percent \\
\hline $\begin{array}{l}\text { Student-centered (Students interact with instructor and one } \\
\text { another) }\end{array}$ & 0 & 0 \\
\hline Teacher-centered (Instructor talks, and students listen) & 2 & 20 \\
\hline Mixed Methods (Student-centered with Teacher-centered) & 8 & 80 \\
\hline Total & $\mathbf{1 0}$ & $\mathbf{1 0 0}$ \\
\hline
\end{tabular}

\section{Teaching $\operatorname{Method}(s)$}

The course instructor adopted precise teaching methods to facilitate the process of knowledge transference to students and to accommodate the majority of students learning styles. Respondents ranked the teaching methods used as indicated in Table 5. The number one ranked method was discussion followed by lecturing, then demonstration; this ranking is in agreement with the students' perception of the teaching approach used by instructor (Mixed Methods) as indicated by respondents' answers of questionnaire first question.

Table 5. Course Teaching Methods

\begin{tabular}{|l|c|c|}
\hline Teaching Method & Frequency & Rank \\
\hline Discussion & 9 & 1 \\
\hline Lecturing & 6 & 2 \\
\hline Demonstration or Experiment & 5 & 3 \\
\hline Case Study & 2 & 4 \\
\hline
\end{tabular}




\section{Evaluation of Teaching Methods}

Respondents evaluated the teaching methods applied as being "Very helpful" with an overall mean of 4.4 on a five-point Likert scale; see Table 6.

Table 6. Teaching Methods Evaluation

\begin{tabular}{|l|c|c|}
\hline Evaluation of Teaching Methods & Frequency & Percent \\
\hline Very helpful & 6 & 60 \\
\hline Extremely helpful & 4 & 40 \\
\hline Total & $\mathbf{1 0}$ & $\mathbf{1 0 0}$ \\
\hline \multirow{2}{*}{ Overall Evaluation of Teaching Methods } & Mean & Std. Deviation \\
\cline { 2 - 3 } & 4.40 & 0.52 \\
\hline
\end{tabular}

Note: 5=Extremely helpful, 4=Very helpful, 3=Somewhat helpful, 2=Not so helpful, 1=Not at all helpful.

Such results indicate that students learning process was successful and the teaching methods used were effective in providing knowledge to students suiting their learning styles and preferences.

\section{Practical Application Location Preference}

Based on previous years students feedback a shift from commercial properties as a training location to catering facilities on SQU premises took place. Respondents' answers reveal that there is a growing tendency to switch to commercial properties once more, as $40 \%$ of students are in favor of this switch (see Table 7). This tendency could be resolved by splitting practical application weeks into two and conducted at commercial and institutional food and beverage operations equally.

Table 7. Training Location Preference

\begin{tabular}{|l|c|c|}
\hline Location & Frequency & Rank \\
\hline Catering facilities on SQU premises & 6 & 1 \\
\hline Commercial restaurants & 4 & 2 \\
\hline Total & $\mathbf{1 0}$ & \\
\hline
\end{tabular}

\section{Suggested Course Improvements}

Respondents suggested the following points to improve the course:

- Visiting commercial restaurants/Field trips

- More educational videos related to course topics.

- Tasting food.

- Meeting restaurants managers. 


\section{Part C: Courses Instructors Feedback}

As it is important to assess students' feedback on the practical training of food production and service in hospitality courses, it is also important to study both courses instructors' feedback. Over the last 10 years two instructors were responsible for teaching those courses, their comments tackled three main issues:

\section{Employability and Job Opportunities}

“...Graduates never work in the field..." (Instructor $1 \& 2$ )

"...They may join a management training program or at least, they join as supervisors ... For a while..." (Instructor 1)

Several studies by field specialists (Al-Balushi 2008, UNWTO and MOT 2011) indicated that Omani hospitality discipline graduates do not work in the field, especially, they stand-away of working in food production or service. Tourism Department graduates' enrolment in the industry workforce is so limited, they mainly choose the government (public) sector (Atef 2018). Job opportunities in indirectly related fields is the reason that the Hospitality Management Specialization is still surviving, in many cases, employers do not differentiate between specializations, for them they are all "Tourism Department Graduates".

\section{Specialization Image and Students' Attitude}

"...Students call it "Hospitality", while the other specialization they call it "Tourism Management", perceiving it at a higher level than the Hospitality Management Specialization..." (Instructor $1 \& 2$ )

"...Those courses shut off students...they feel ridiculed by others when going for the course practical application wearing the required uniform..." (Instructor 2)

There exists a problem convincing students to wear the uniforms required for both courses. For the kitchen uniform the problem was solved replacing the chef coat with a lab coat, it suited the students and posed no problem in the kitchen, but for the service pants, white shirt, and bow tie it was not easy, they hide and keep away of serving as much as they can, the absenteeism rate is higher in this course than the Food Production course.

\section{Study Plan Amendments and Development}

"...Avoid problems, do not create them then try to find out solutions...this type of practical courses hinders students from joining the "Hospitality Management Specialization" and even the "Tourism Department" itself..." (Instructor 1 \& 2)

“...One F\&B Management course....As a solution, a F\&B Management course could be offered replacing both courses..." (Instructor 1)

These statements question the benefits behind teaching those courses in the current form. Are we constructing the conceptual model that guides hospitality 
curricula formation based on sound solid academic rules and best practices or based on trends, preferences, community, and traditions? We are to serve the community and look for its best interest while adhering to the scientific pillars of the discipline we are affiliated to. The one F\&B Management course is a good solution to overcome that low level perception of the two courses that is at the same time affecting the whole Hospitality Management Specialization.

"...We have to reconsider the practical courses but at the same time correlating this with the two Internship Courses..." (Instructor $1 \& 2$ )

"...Shadowing is the key..." (Instructor 1)

Practical courses cannot be discussed or evaluated apart from Internship Courses. Internship1 is a general training course that familiarizes students with the tourism and hospitality industry, while Internship 2 is a specialized course that gives students a closer perspective of the industry branch they chose to study. A wholistic overview of internship courses is in need. The construction of the internship courses could be amended to be both related to students' specialization in the shape of two "Shadowing" programs, so for the Hospitality Management Specialization it would be: F\&B Manager Shadowing (Internship1), then Rooms Division Manager Shadowing (Internship 2).

\section{Conclusions and Recommendations}

The current study aims to evaluate the teaching and learning experience of the two practical Hospitality Management Specialization courses: Food Production course and Service in Hospitality course.

From a managerial perspective, the study outcomes are important in evaluating the practical courses status leading to an enhanced teaching and learning experience and at the same time is a step towards the reformulation and update of the undergraduate program study plan. Students' evaluations and responses were straight forward while instructors' comments were thorough, correlating the investigated courses to the other study plan courses showing their wholistic effect on the program. There were concerns about the sustainability of the Hospitality Management Specialization and consequently, the Tourism Department itself, which requires reconsidering the academic conceptual model adopted and study plan structure. The following are the study recommendations and proposed courses of action:

\section{Tactical Courses of Action}

- Improving practical courses teaching and learning experience and the related logistics. Mixed teaching methods approach should be continuously adopted as it suits the course nature. Besides lecturing: guest speaker and field visits, discussions, and visual aids are the most suitable teaching methods based on the course nature. Movies pertaining to each, and every 
course topic should be ready and used. In-class basic practical application could be applied to prepare students to the field training part.

- Practical application weeks could be split into two and conducted at commercial and institutional food and beverage properties equally.

- Training should be horizontal concentrating on hospitality properties departments and functional areas rather than vertical concentrating on levels and positions.

- Amendments to current study plan, introducing new courses to help and support graduates' employability.

- Proper preparation of students creating an understanding of the surrounding social and economic environments that students/graduates will be part of upon their transition to be part of the local workforce.

\section{Strategical Courses of Action}

- Tactically the movement between institutional and commercial settings has been smooth and has overcome pressing issues, but strategically an overall reconsideration of the hospitality specialization study plan is urgently needed.

- The study plans should be updated considering the societal constraints and market needs, neither factors should be neglected or else we would be moving in circles that leads to nothing.

- A F\&B Management course could be offered replacing both courses (Food Production \& Service in Hospitality)

- Internship courses could be amended to be related to students' specialization of choice. Shadowing programs would be a more beneficial and practical alternative to the long-time applied internship courses.

- Academics and stakeholders should have collaborative inputs concerning the structure and conceptual model of the study plan based on each party's experience and track.

- To better structure and implement courses and study plans, instructors should be familiar with industry needs, work environments, and industry mindset. Practical industry experience is an added value. A mechanism should be created and adopted to assure that academics be updated of the industry needs and trends: workshops on regular basis, advisory committee meetings, etc.

- Auditing and peer review practices are to be implemented on regular basis to control and assure teaching and learning experience quality.

\section{References}

Al-Balushi M (2008) Omani employment and the development of careers in the hotel sector in the Sultanate of Oman. Doctoral Dissertation. Cardiff, Wales, UK: University of Wales. 
Atef T (2018) A tourism and hospitality education management model: the case of the tourism department of Sultan Qaboos University. Journal of Tourism and Hospitality Management 6(1): 39-54.

Atef T, Al-Balushi M (2015) Entrepreneurship as a means for restructuring employment patterns. Tourism and Hospitality Research 15(2): 73-90.

Atef T, Al-Balushi M (2017) Omani tourism and hospitality students' employment intentions and job preferences: ramifications on Omanization plans. Quality Assurance in Education 25(4): 440-461.

Balula A, Moreira G, Moreira A, Kastenholz E, Euśebio C, Breda Z (2019) Digital transformation in tourism education. Tourism in Southern and Eastern Europe 5(Sep): 61-72.

Boella M, Goss-Turner S (2005) Human resource management in the hospitality industry: an introductory guide. 8th Edition. Oxford, UK: Butterworth-Heinemann.

Canny A (2002) Flexible Labor? The Growth of Student Employment in the U.K. Journal of Education and Work 15(3): 277-301.

Chen T, Shen C, Gosling M (2018) Does employability increase with internship satisfaction? Enhanced employability and internship satisfaction in a hospitality program. Journal of Hospitality, Leisure, Sport and Tourism Education 22(Jun): 8899.

Cho S, Erdem M, Johanson M (2006) Hospitality graduate education: a view from three different stakeholder perspectives. Journal of Hospitality and Tourism Education 18(4): 45-55.

Dawson M (2014) Preparing students to fit within the hospitality industry culture: does the educational background make a difference? Journal of Teaching in Travel and Tourism 14(1): 53-68.

Finn M, Elliot-White M, Walton M (2000) Tourism and leisure research methods: data collection, analysis and interpretation. Essex, UK: Pearson Education Limited.

Forrest L (1996) Training for the hospitality industry. $2^{\text {nd }}$ Edition. Michigan, USA: E.I. of The American Hotel and Motel Association.

Go F, Monachello M, Baum T (1996) Human resource management in the hospitality industry. New York, USA: John Wiley and Sons.

Gould N (2000) Becoming a learning organization. Social Work Education 19(6): 585-596.

Harvey L (2010) New realities: the relationship between higher education and employment. Tertiary Education and Management 6(1): 3-17.

Heathfield S (2020, January 3) Job shadowing is effective on-the-job training. The Balance Careers.

Inui Y, Wheeler D, Lankford S (2006) Rethinking tourism education: what should schools teach? Journal of Hospitality, Leisure, Sport and Tourism Education 5(2): 25-35.

Jauhari V, Manaktola K (2006) Comparison of internship experiences in foodservice firms in India and UK. Journal of Food Service Business Research 9(2/3): 187-206.

Koc E, Yumusak S, Ulukoy M, Kilic R, Toptas A (2014) Are internships programs encouraging or discouraging? A viewpoint of tourism and hospitality students in Turkey. Journal of Hospitality, Leisure, Sports and Tourism Education 15(Jul): 135142.

Lee M, Olds D, Lee C (2010) Why students choose a hospitality and tourism program: a pilot study of U.S. undergraduate students. Journal of Hospitality and Tourism Education 22(3): 20-26.

Mader F, Mader D, Alexander E (2017) Job shadowing experiences as a teaching tool: a new twist on a tried and true technique. Atlantic Marketing Journal 5(3): Article 8. 
Mahmoud E (2018) Is private higher education on the right path? The case of hotel studies education in Egypt. Journal of Hospitality and Tourism Education 30(1): 19-35.

McCarthy P, McCarthy H (2006) When case studies are not enough: integrating experiential learning into business curricula. Journal of Education for Business 81 (4): 201-204.

$\mathrm{Ng}$ E, Burke R (2006) The next generation at work-Business students' views, values and job search strategy: Implications for universities and employers. Education and Training 48(7): 478-492.

Nguyen N, LeBlanc G (2021) The impact of service employees and servicescape on customers' perception of quality improvement efforts. Athens Journal of Business \& Economics 7(2): 123-144.

Odio M, Wells J, Kervin S (2014) Full-time student, part-time employee: capturing the effects of socialization influences on affective commitment for student employees. Event Management 18(3): 325-336.

Patiar A, Benckendorff P, Kensbock S, Wang Y, Wilkins H, Robinson R, et al. (2019) Enhancing student employability skills through virtual field trips in the hospitality industry. Brisbane, Australia: Griffith University.

Peterson D, Hicks M (1996) Leader as coach: strategies for coaching and developing others. Minneapolis, Minn., USA: Personnel Decisions International.

Ring A, Dickinger A, Wöber K (2009) Designing the ideal undergraduate program in tourism: expectations from industry and educators. Journal of Travel Research 48(1): $106-121$.

Rony Z, Lubis F, Rizkyta A (2019) Job shadowing as one of the effective activities in the promotion process creates quality managers. International Journal of Recent Technology and Engineering (IJRTE) 8(2S): 388-396.

Ruhanen L (2005) Bridging the divide between theory and practice: experiential learning approaches for tourism and hospitality management education. Journal of Teaching in Travel and Tourism 5(4): 33-51.

Ryan P, Horton-Tognazzini L, Williams A (2016) A snapshot of MOOCs in hospitality and tourism. Journal of Hospitality and Tourism Education 28(2): 107-112.

Schoffstall D, Brown E, Arendt S (2017) Hospitality and tourism student and alumni perspectives: promotion expectations, academic and experience adjustments, and career growth. Journal of Teaching in Travel \& Tourism 14(3): 189-207.

Shardlow S, Doel M (1996) Practice learning and teaching. Basingstoke, UK: Macmillan.

Sommerville K (2007) Hospitality employee management and supervision: concepts and practical applications. New Jersey, USA: John Wiley and Sons Inc.

Statt D (2000) Using psychology in management training. London, UK: Routledge.

Tannenbaum S, Mathieu J, Salas E, Cannon-Bowers J (1991) Meeting trainee's expectations: the influence of training fulfilment on the development of commitment, self-efficacy, and motivation. Journal of Applied Psychology 76(6): 759-769.

Tepeci M, Seo W, Upneja A, DeMicco F (2001) Supply and demand for hospitality/ tourism management faculty in the United States. Journal of Hospitality and Tourism Education 13(2): 38-48.

Tucker E, Clarke J (2014) Using Twitter for student engagement and skill learning in a hospitality human resources management course. Consortium Journal of Hospitality and Tourism 19(1): 1-21.

United Nations World Tourism Organization - UNWTO, Omani Ministry of Tourism MOT (2011) Tourism manpower and training needs analysis and tourism human resources development action plan (2011-2015). Unpublished Document. UNWTO, MOT. 
Wang Y (2013) Constructing career competency model of hospitality industry employees for career success. International Journal of Contemporary Hospitality Management 25(7): 994-1016.

Wu B, Morrison A, Yang J, Zhou J, Cong L (2014) Cracks in the Ivory tower? A surveybased analysis of undergraduate tourism education and educators in China. Journal of Hospitality, Leisure, Sport and Tourism Education 14(Apr): 26-38. 